\title{
Genetic Parameters of Some Wheat (Triticum aestivum L.) Genotypes Using Factorial Mating Design
}

\author{
A. E. Badran $^{1} \&$ E. S. A. Moustafa ${ }^{1}$ \\ ${ }^{1}$ Genetic Resources Department, Desert Research Center, Cairo, Egypt \\ Correspondence: A. E. Badran, Genetic Resources Department, Desert Research Center, Cairo, Egypt. E-mail: \\ dr.ayman_badran@yahoo.com
}

Received: October 21, 2014 Accepted: November 3, 2014 Online Published: December 15, 2014

doi:10.5539/jas.v7n1p101 URL: http://dx.doi.org/10.5539/jas.v7n1p101

\begin{abstract}
Using parents and mating designs appropriate in the field of conventional plant breeding are the beginning to successful plant breeding program. However, there are many factors that influence their choices of mating designs, such as genetic parameters, experimental conditions and other biological constraints used in the evaluation process. In this study, Two wheat (Triticum aestivum L.) genotypes used as males while, fifteen used as females were assessed for yield and yield associated traits using North Carolina Design II (factorial mating design). The seventeen parents and their $30 \mathrm{~F} 1$ progenies were planted in randomized complete block design with three replications in three sets, during the growing season 2009/2010 and 2010/2011 in Ras-Sudr Regoin , South of Sinai, Egypt. Highly significant differences among males, females and hybrids between them were observed for all traits except No. of tillers and weight of grains /spike for females and the hybrids between males and females. The dominance genetic variance was higher than additive genetic variance for all studied traits except grain and straw yield per plant. Both heritability in narrow sense and expected genetic advance as percent were relatively high for spike weight grain yield and straw yield per plant. Depending on the previous genetic parameters we can achieve a quick and easy insight to a successful assessment.
\end{abstract}

Keywords: wheat, additive, dominance, heritability, genetic variance

\section{Introduction}

Wheat (Triticum aestivum L.) is the main staple food in Egypt and it occupies a prominent position in the cropping pattern of the country. So, there is a great deal of research work in the field of wheat breeding through genetic variability. However increasing population and climate changes in the country require the breeders for further breakthrough in this food crops. For achieving an improvement in the heritable traits and estimation of genetic parameters is paramount importance in any breeding programme. In plant breeding, various mating designs and arrangements are used by breeders and geneticists to generate improved plants. The selection of suitable parents and good mating designs are keys to a successful plant breeding schemes (Khan et al., 2009). However, there are several factors affecting the choices of mating designs. Mating design refers to the procedure of producing the progenies, in plant breeding, plant breeders and geneticists, theoretically and practically, they use different forms of mating designs and arrangements for targeted purpose. The choice of a mating design for estimating genetic variances should be dictated by the objectives of the study, time, space, cost and other biological limitations. The analysis of variance can be adopted to estimate the components of variances. Therefore, this review aimed at highlighting the most used mating design in plant breeding and genetics studies. It provides easy and quick insight of the different form of mating designs and some statistical components for successful plant breeding (Hallauer et al., 2010). The North Carolina mating design II (factorial mating design) is one of the most widely used genetic designs in plant breeding programs to identify the best parents for hybrid formation, identify superior hybrids, and to assign lines to new heterotic groups (Hallauer \& Miranda, 1988). Genetic variability is essential in order to realize response to selection pressure as the estimation of genetic parameters of variation are specific for a particular population and the phenotypic expression of the quantitative character may be altered by environmental stress that affect plant growth and development. In a population under selection for a quantitative character, genotypic frequencies and hence gene frequencies are altered and these changes are further modified by the mating systems that may be employed to advance the selected individuals to the next generation(s) (Chopra, 2000). Thus, the utilization of any criterion for selection is linked with high 
genetic coefficient of variation and estimates of heritability as the magnitudes of heritability and other genetic parameters for a character would vary from location to location and the importance of estimatation heritability with genetic advance to predict the resulting effect of selecting Johnson et al. (1955) and Ramachandran et al. (1982).

\section{Material and Methods}

Genotypes used in this study were seventeen wheat genotypes, two wheat (Triticum aestivum L.) genotypes used as males while fifteen genotypes used as females. The pedigree of these wheat genotypes are shown in Table 1 were assessed for grain and straw yield and yield associated traits using factorial mating design (North Carolina mating design II). In 2009/2010 and 2010/2011 growing seasons, each of fifteen wheat genotypes were crossed to low performing one i.e., (Azeghar-2/3/Mrf2//Bcr/Gro1) and high performing parent (Gemiza 7) to produce the F1 seeds. The seventeen parents (two males and fifteen female) and their $30 \mathrm{~F} 1$ progenies were planted in randomized complete block design with three replicates in three sets in Ras-Sudr, South of Sinai, Egypt, (electrical conductivity of soil was 3.8 and water $7.6 \mathrm{mmhos} / \mathrm{cm}$ and $\mathrm{pH} 7.1$ during the growing seasons 2009/2010 and 2010/2011) according to Comstock and Robinson, 1952 and Singh and Narayanan1993. Each replicates consists of 2 rows (beside that 2 rows as a guard), one row for each genotype; $15.0 \mathrm{~m}$ long and the distance maintained between rows and between plants were $75 \mathrm{~cm}$ and $25 \mathrm{~cm}$, respectively. Data were recorded on various parameters, viz; plant height $(\mathrm{cm})$, No of tillers/plant, spike length, No. of spikelet's/spike, weight of grains/spike, 1000-grain weight (g), No. of grains/ spike and both grain and straw yield/plant (g).

Table 1. Pedigree of seventeen investigated genotypes and the gender of parents used in hybridization

\begin{tabular}{lll}
\hline Code & Gender & Pedigree name \\
\hline V1 & + & (Mrb5/T.dicds600545//Mrb5)903/3/Stj3//Bcr/Lks4/4/Icasyr-1 \\
V2 & + & Azeghar-2//Wdz6/Gil4 \\
V3 & + & Ouasbar-3/3/Topdy-18/Focha-1//Altar 84 \\
V4 & o & Azeghar-2/3/Mrf2//Bcr/Gro1 \\
V5 & + & Azeghar-2/Murlagost-1 \\
V6 & + & ICAMOR-TA04-63/Arislahn-5 \\
V7 & + & 319-ADDO/5/D68-1-93A-1A//Ruff/Fg/3/Mtl-5/4/Lahn \\
V8 & + & Icasyr-1/4/Assassa//Waha/Brch/3/Bicrederaa1 \\
V9 & + & MORL-F38//Bcrch1/Kund1149/3/Bicrederaa1/Miki \\
V10 & + & Mrf1/Stj2/3/1718/BT24//Karim \\
V11 & + & Bcr/Gro1//Mgnl1 \\
V12 & + & Geromtel-1/Icasyr-1 \\
V13 & + & Azeghar-2/Murlagost-2 \\
V14 & + & 1364-OTDO//Lgt3/Bcrch1/3/Quasnima-1 \\
V15 & + & MORL-F38//Bcrch1/Kund1149/3/Bicrederaa1/Miki \\
V16 & + & Msbl1//Awl2/Bit/3/1718/BT24//Karim/4/Assassa//Waha/Brch/3/Bicrederaa1 \\
V17 & o & CMH74 A. 630/5x//Seri 82/3/Agent (Gemiza 7) \\
\hline ; $:$ male; & code: serial number of genotypes from v1:v17.
\end{tabular}

\subsection{Estimation of Genetic Variance}

The analysis of variance, the variance components and expected mean square were estimated in Table 2 using software of SAS program. The factorial mating design allowed estimation of some genetic variance components (additive and dominance variance) according to Singh and Narayanan (1993) design. Where, we assumed that epistasis variance was negligible and that the inbreeding coefficient of the parents was zero. The formulas for estimation of genetic variation components calculated according to Foster and Shaw (1988), Lynch and Walsh (1998) and Gilmour et al. (2006) as follows: additive variance within female population: VA $f=4 \sigma^{2} f$, additive variance within male population: VA $m=4 \sigma^{2} m$, additive variance estimated for the hybrid population is average of $\sigma^{2} \mathrm{~A} f$ and $\sigma^{2} \mathrm{~A} m$ : VA $=2\left(\sigma^{2} m+\sigma^{2} f\right)$ and the variance of dominance effects will be defined as: $\mathrm{VD}=4\left(\sigma^{2} m\right.$ $f)$. 
Table 2. Analysis of variance and expected mean squares

\begin{tabular}{|c|c|c|c|}
\hline S.O.V & d.f & M.S & E.M.S \\
\hline Set (S) & (s-1) & & \\
\hline Replication within sets & $\mathrm{S}(\mathrm{r}-1)$ & & \\
\hline Male (M) within sets & $\mathrm{s}(\mathrm{m}-1)$ & M4 & $\sigma^{2} \mathrm{e}+\mathrm{r} \sigma^{2} \mathrm{fm}+\mathrm{rf} \sigma^{2} \mathrm{~m}$ \\
\hline Female (F) within sets & $s(f-1)$ & M3 & $\sigma^{2} e+r \sigma^{2} f m+r m \sigma^{2} f$ \\
\hline$\left(\mathrm{M}^{*} \mathrm{~F}\right)$ within sets & $\mathrm{s}(\mathrm{m}-1)(\mathrm{f}-1)$ & M2 & $\sigma^{2} \mathrm{e}+\mathrm{r} \quad \sigma^{2} \mathrm{fm}$ \\
\hline Error & $\mathrm{s}(\mathrm{mf}-1)(\mathrm{r}-1)$ & M1 & $\sigma^{2} \mathrm{e}$ \\
\hline
\end{tabular}

S.O.V: source of variance; d.f: degree of freedom; M.S: mean square; E.M.S: expected mean square.

\subsection{Estimation of Heritability and Expected Genetic Advance}

- $\quad$ Total genetic variance $(\mathrm{VG})$ of the hybrid population can be calculated by the following equation: $V G=V A$ $+\mathrm{VD}$ and Phenotypic variance $(\mathrm{VP})$ can be calculated by the following equation: $\mathrm{VP}=\mathrm{VG}+\mathrm{VE}=(\mathrm{VA}+\mathrm{VD})+$ VE

- Heritability in the narrow sense $\mathrm{H}^{2}$ (ns) was estimated by using the following equations: $\mathrm{H}^{2} \mathrm{~ns}=\mathrm{VA} / \mathrm{VP}$ where, $\mathrm{VA}=$ additive variance, $\mathrm{VP}=$ Phenotypic variance, and Expected genetic advance $(\mathrm{EGA})=\left(\mathrm{H}^{2} \mathrm{~ns}\right)(\sigma \mathrm{P})$ (i) where, $\sigma \mathrm{P}=$ Phenotypic standard deviation, $\mathrm{i}=$ Coefficient of selection which is 2.06 at $5 \%$ selection intensity and expected genetic advance as a percent of mean: $(\mathrm{EGA} \%)=(E G A / \ddot{x}) \times 100$ where, $\ddot{\mathrm{x}}=$ grand mean of each trait.

\section{Results and Discussion}

\subsection{Mean Performance}

The analysis of variance showed that the mean squares for all traits are presented in Table 3. Means sum of squares due to males (M) within sets were high significant for all studied characters. Also, the means sum squares for females (F) were significant for all traits except No. of tillers and weight of grains/spike and the same content for hybrids between males and females $(\mathrm{M} * \mathrm{~F})$ in addition to spike weight. That indicated the existence of a high degree of genetic variability to be exploited in breeding program, and it reflected the broad ranges observed for each trait. These findings are in accordance with Asif et al. (2004) who also observed significant variability in wheat germplasm. Hence, it could be noted that, indicates selection for different quantitative characters could be selected for improvement in wheat yield.

Table 3. Mean square of parents and hybrids for the studied characters

\begin{tabular}{|c|c|c|c|c|c|c|c|c|c|c|c|}
\hline \multirow[b]{2}{*}{ S.O.V } & \multirow[b]{2}{*}{ d.f } & \multicolumn{10}{|c|}{ M.S. } \\
\hline & & $\begin{array}{l}\text { Plant } \\
\text { height }\end{array}$ & $\begin{array}{l}\text { No.of } \\
\text { tillers }\end{array}$ & $\begin{array}{l}\text { Spike } \\
\text { length }\end{array}$ & $\begin{array}{l}\text { No.of } \\
\text { spikelet's } \\
\text { /spike }\end{array}$ & $\begin{array}{l}\text { Spike } \\
\text { weight }\end{array}$ & $\begin{array}{l}\text { Weight } \\
\text { of grains } \\
\text { /spike }\end{array}$ & $\begin{array}{l}1000 \text { grain } \\
\text { weight }\end{array}$ & $\begin{array}{l}\text { No.of } \\
\text { grains } \\
\text { /spike }\end{array}$ & $\begin{array}{l}\text { Grain } \\
\text { yield }\end{array}$ & Straw yield \\
\hline Set(S) & 2 & 4.97 & 4.40 & 0.95 & 3.94 & 0.23 & 0.04 & 6.52 & 3.63 & 57.40 & 682.11 \\
\hline$S(r-1)$ & 6 & 0.43 & 0.06 & 0.04 & 0.04 & 0.01 & 0.01 & 0.17 & 0.03 & 0.27 & 0.82 \\
\hline Male (M) & 3 & $788.56^{* *}$ & $20.91 * *$ & $47.91^{* *}$ & $21.38 * *$ & $37.18 * *$ & $13.13 * *$ & $403.13 * *$ & $2282.11 * *$ & $583.87^{* *}$ & $4963.24 * *$ \\
\hline Female(F) & 42 & $146.29 * *$ & $0.95 \mathrm{~ns}$ & $2.20 * *$ & $6.07 * *$ & $2.06 * *$ & $0.80 \mathrm{~ns}$ & $17.06^{* *}$ & $272.99 * *$ & $29.44 * *$ & $252.14 * *$ \\
\hline $\mathbf{M} * \mathbf{F}$ & 42 & $122.49^{* *}$ & $0.88 \mathrm{~ns}$ & $2.07 * *$ & $7.21 * *$ & $1.47 \mathrm{~ns}$ & $0.57 \mathrm{~ns}$ & $17.77 * *$ & $176.73^{* *}$ & $16.68 * *$ & $152.92 * *$ \\
\hline Error & 174 & 0.11 & 0.20 & 0.02 & 0.05 & 0.01 & 0.01 & 0.09 & 0.04 & 0.30 & 0.57 \\
\hline
\end{tabular}

*, **, ns: significant at $5 \%$ and $1 \%$ probability level and not significant respectively.

\subsection{Gene Action and Other Genetic Parameters}

Estimates of environmental (VE), additive (VA), dominance (VD), and variances for studied traits are presented in Table 4. The values of dominance genetic variance were greater than additive genetic variance for all studied characters except grain and straw yield per plant and these results depicts the importance of dominant gene effect for controlling these traits. Such results were also reported by Kage et al. (2013). At the same time, the lowest values of narrow sense heritability $(0.195$ and 0.029$)$ were obtained for plant height and number of spikelet's / 
spike respectively and these results indicated that these traits were affected by over-dominance effects of some genes controlling the characters under study which is reflected in the low narrow-sense heritability. Similar results were recorded by Shahrokhi et al. (2013) whom also showed the importance of dominance relative to additive genetic effects by using generation mean analysis method. On the other hand, both grain and straw yield per plant recorded the highest values of additive genetic variance (31.26 and 262.14) respectively and the highest values of narrow sense heritability $(0.585$ and 0.563$)$ which indicated greater proportion of additive genetic variation suggesting possible improvement in early generations depending on these traits using selection for these traits (Hayman, 1958 ). In the same manner, Sardana et al. (2007), suggested that high heritability may not necessarily lead to increased genetic gain, unless sufficient genetic variability existed in the germplasm.

\subsection{Heritability and Genetic Advance}

It has been stressed that without expected genetic advance, the Heritability values would not be of practical importance in selection based on phenotypic appearance. According to Ansari et al. (2004) who reported that, high heritability percentage reflects the large heritable variance which may offer the possibility of improvement through selection. However, the estimation of heritability and genetic advance as percentage mean considered together will no doubt help in drawing conclusion about the nature of gene action governing a particular character (Johnson et al., 1955). That was due to the fact that combined study of heritability and genetic advance is more reliable in forecasting the effect of selection. So, genetic advance should be considered along with heritability in coherent selection breeding program. Estimation of heritability in narrow sense $\left(\mathrm{H}^{2} \mathrm{~ns}\right)$ and expected genetic advance (EGA\%) as percentage of each trait mean are shown in Table 4. In the present investigation, moderate to high heritability values relative in narrow sense $(0.585,0.563$ and 0.493$)$ coupled with high expected genetic advance (108.94, 107.44 and $42.05 \%)$ were recorded for Grain yield per plant, straw yield per plant and spike weight respectively (Table 4$)$. In the same manner, low heritability values in narrow sense $(0.029$ and 0.195$)$ was accompanied by low expected genetic advance as a percentage of each trait mean $(0.97$ and 5.64\%) for the number of spikelet's per spike and plant height, respectively. That gives promises for selection of progenies with high heritability values in narrow sense and expected genetic advance values depending on selection for grain yield per plant, straw yield per plant and spike weight traits in early segregating generations. While, number of spikelet's per spike and plant height that showed low $\mathrm{H}^{2}(\mathrm{n} . \mathrm{s})$ and low EGA\% showing preference of heterosis for improvement of this trait. Similar findings were also reported by Waqar et al. (2008) who reported that grain yield per plant displayed high heritability estimates with relatively high value of genetic advance. While, Pawar et al. (2002) reported that, plant height, number of tillers exhibited higher heritability.

Table 4. Estimation of components of variance and genetic parameters for different traits in wheat

\begin{tabular}{lllllll}
\hline Character & (VE) & $(\mathrm{VA})$ & $(\mathrm{VD})$ & $(\mathrm{Vph})$ & $\mathrm{H}^{2}(\mathrm{n} . \mathrm{s})$ & $\mathrm{EGA}(\%)$ \\
\hline Plant height & 0.107 & 39.65 & 163.18 & 202.94 & 0.195 & 5.64 \\
No. of tillers & 0.192 & 0.98 & 0.92 & 2.08 & 0.468 & 41.14 \\
Spike length & 0.025 & 2.23 & 2.72 & 4.97 & 0.448 & 17.11 \\
No. of spikelet's/spike & 0.049 & 0.29 & 9.55 & 9.89 & 0.029 & 0.97 \\
Spike weight & 0.008 & 1.90 & 1.94 & 3.85 & 0.493 & 42.05 \\
Weight of grains/spike & 0.005 & 0.67 & 0.75 & 1.43 & 0.471 & 32.97 \\
1000 grain weight & 0.087 & 18.12 & 23.57 & 41.78 & 0.434 & 10.68 \\
No. of grains/spike & 0.039 & 132.35 & 235.58 & 367.97 & 0.359 & 22.97 \\
Grain yield/plant & 0.300 & 31.26 & 21.84 & 53.41 & 0.585 & 108.94 \\
Straw yield/plant & 0.574 & 262.14 & 203.12 & 465.83 & 0.563 & 107.44 \\
\hline
\end{tabular}

VE: environmental variance; VA: additive variance; VD: dominance variance; VP: Phenotypic variance; $\mathrm{H}^{2}(\mathrm{n} . \mathrm{s})$ : Heritability narrow sense; EGA: expected genetic advance.

\section{Conclusion}

The present study indicated that we can depend on additive variance through grain yield per plant and straw yield per plant in early generations selection for improvement in wheat yield and these finding are consistent with results of both heritability and expected genetic advance. On the other hand, we can use dominance 
variance through No. of grains/spike, plant height and No. of spikelet's/spike in hybrid vigor in F1 generation.

\section{References}

Ansari, B. A., Ansari, K. A., \& Khund, A. (2004). Extent of heterosis and heritability in some quantitative characters of bread wheat. Indus. J. Pl. Sci., 3, 189-192.

Asif, M., Mujahid, M. Y., Kisana, N. S., Mustafa, S. Z., \& Ahmad, I. (2004). Heritability, genetic variability and path coefficient of some traits in spring wheat. Sarhad J. Agric., 20, 87-91.

Chopra, V. L. (2000). Plant breeding - Theory and practice (2nd ed., p. 10). Oxford and IBH Pub. Co. Pvt. Ltd, New Delhi.

Comstock, R. R., \& Robinson, H. F. (1952). Genetic parameters, their estimation and significance. Proc. 6th International Grassland Congress (Vol. 1, pp. 248-291). Nat. publ. Co. Wash., D.C., U.S.A.

Foster, G. S., \& Shaw, D. V. (1988). Using clonal replicates to explore genetic variation in a perennial plant species. Theo. Appl. Genet., 76, 788-794. http://dx.doi.org/10.1007/BF00303527

Gilmour, A. R., Gogel, B. J., Cullis, B. R., \& Thompson, R. (2006). ASReml User Guide, Release 2.0. VSN International, Hemel Hempstead, UK.

Hallauer, A. R., \& Miranda, J. B. (1988). Quantitative Genetics in Maize Breeding. Iowa State University Press, Ames, Iowa. USA.

Hallauer, A. R., Carena, M. J., \& Filho, J. B. M. (2010). Quantitative genetics in maize breeding. Handbook of plant breeding 6. Springer Science Business Media, LLC, Iowa, USA.

Hayman, B. I. (1958). The theory and analysis of diallel crosses. Genetics, 43, 63-85.

Johnson, H. W., Robinson, H. F., \& Comstock, R. E. (1955). Estimation of genetic and environmental variability in soybeans. Agro. J., 47, 314-318. http://dx.doi.org/10.2134/agronj1955.00021962004700070009x

Kage, U., Wali, M. C., Madalageri, D., Natikar, P., \& Gangashetty, P. (2013). Gene action and heterosis study in hybrids derived from new inbred lines in maize (Zea mays L.). Mol. Plant Breeding, 4(18), 146-149.

Khan, S. A., Ahmad, H., Khan, A., Saeed, M., Khan, S. M., \& Ahmad, B. (2009). Using Line x Tester analysis for earliness and plant height traits in Sunflower (Heliathus annuus L.). Rec. Res. Sci. Tech., 1, 202-206.

Lynch, M., \& Walsh, B. (1998). Genetics and analysis of quantitative traits. Sinauer Associates, Sunderland, MA.

Pawar, S. V., Patil, S. C., Naik, R. M., \& Jambhale, V. M. (2002). Genetic variability and Heritability in wheat. $J$. of Maharashtra Agri., 27(3), 324-325.

Ramachadran, C., Peter, K. V., \& Gopalakrishnan, P. K. (1982). Variation in selected varieties of cowpea (Vigna unguiculata (L.) Walp.). Agric. Res. Karale, 18(1), 94-97.

Sardana, S., Mahjan, R., Gautam, N., \& Ram, B. (2007). Genetic variability in pea (Pisum sativum L.) germplasm for utilization. SABRAO J. Breed. Genet., 39(10), 31-41.

Shahrokhi, M., Khorasani, S. K., \& Ebrahimi, A. (2013). Study of genetic components in various maize (Zea mays L.) traits using generation mean analysis method. Intl. J. Agron. \& Plant Prod., 4(3), 405-412.

Singh, P., \& Narayanan, S. S. (1993). Biometrical techniques in plant breeding (p. 249). Kalyani, Publishers Ludhiana, India.

Waqar, U. H., Malik, M. F., Rashid, M., Munir, M., \& Akram, Z. (2008). Evaluation and estimation of heritability and genetic advancement for yield related attributes in wheat lines. Pak. J. Bot., 40(4), 1699-1702.

\section{Copyrights}

Copyright for this article is retained by the author(s), with first publication rights granted to the journal.

This is an open-access article distributed under the terms and conditions of the Creative Commons Attribution license (http://creativecommons.org/licenses/by/3.0/). 